\title{
Mechanical Characteristics of the Main Tower of a Polygonal Line Tower Cable-Stayed Bridge
}

\author{
Yan-feng Li $\mathbb{D}^{1,2}$ Ying $\mathrm{He} \mathbb{D}^{1},{ }^{1}$ and Long-sheng Bao $\mathbb{D}^{1}$ \\ ${ }^{1}$ School of Transportation Engineering, Shenyang Jianzhu University, Shenyang 110168, China \\ ${ }^{2}$ Key Laboratory of Ministry of Education on Safe Mining of Deep Metal Mines, Northeastern University, \\ Shenyang 110819, China \\ Correspondence should be addressed to Ying He; hying9999@126.com
}

Received 9 January 2020; Revised 11 September 2020; Accepted 27 September 2020; Published 8 October 2020

Academic Editor: Tayfun Dede

Copyright (C) 2020 Yan-feng Li et al. This is an open access article distributed under the Creative Commons Attribution License, which permits unrestricted use, distribution, and reproduction in any medium, provided the original work is properly cited.

\begin{abstract}
The main tower of a polygonal line tower cable-stayed bridge bears most of the axial force transmitted by the stay cable and also bears the moment under certain unbalanced load. For a polygonal line tower cable-stayed bridge, the main tower has a bending corner and the direction of huge axial force transmission changes at this bending corner where the axis of the main tower changes. This study examined a cable-stayed bridge with a single cable plane in Shenyang and used model test and finite element numerical comparative analysis to analyze the mechanical properties of the key parts, including the main tower bending corner of the concrete polygonal line tower. The results show a serious stress concentration phenomenon at the bending corner of the main tower but a small range of high stress area. After the stiffening plate is set at the corner, the stress concentration coefficient of the bending corner section decreases and the stiffening plate eliminates the out-of-plane bending phenomenon of the tower wall at the middle span side as vertical tensile stress occurs in the stiffener at the bending corner. Based on these results, the design should be improved to increase the angle of the stiffening plate corner and appropriately strengthen the configuration of the vertical main tensile steel bar and the surface anticracking steel mesh inside the stiffening plate.
\end{abstract}

\section{Introduction}

The important structural components of a cable-stayed bridge are the main beam, the main tower, and the cable stays, in which most of the dead load and live load that the main beam bears are transmitted to the main tower through the cable stays and finally transmitted through the main tower to the foundation [1]. The main tower itself is designed to transmit a huge vertical force.

Recent research on the pylons of cable-stayed bridges has mainly focused on cable-stayed bridges with or without back cables [2-4]. Peng et al. [5] summarized designs of cablestayed bridges without and with backs under construction at home and abroad and discussed in detail the required balance between the tower beam and the access criteria for the cables and the inclination of the tower, finding that reasonable inclination of the tower can be obtained by reducing the influence of the tower weight deviation on the strength of the tower body. Yan et al. [6] systematically studied the influencing factors of the reasonably formed state of a cable-stayed bridge without backstays and deeply analyzed the mechanical properties of the cable-stayed bridge under various parameters, with focus on the inclination of the tower. Wang [7] summarized the structural characteristics of a cable-stayed bridge without a backstay from the three aspects of tower, cable, and beam, studied the structural design and calculation of a cable-stayed bridge without backstay of the leaning tower, and combined this theoretical work with actual engineering structural analysis. Focusing on the Heihe Highway cable-less, cable-stayed bridge, Guoyong Huang studied the natural vibration characteristics, stability characteristics, geometric nonlinearity, and temperature differences of the bridge [8]. Casas described problems encountered in the design and construction of the world's first cableless cable-stayed bridge, Alamiro, providing guidance for the future construction of 
this kind of bridge [9]. Chen et al. [10] proposed use of the "force balance method" to determine the target cable force of a cable-stayed bridge under dead load. This method can easily consider both the prestress and the excess bending moment of the corresponding section. Compared with the traditional "zero displacement" method, this method is more reasonable and simple. Other scholars have studied different aspects of the cable-stayed bridge without backstay, such as reasonable bridge formation, construction control, stability, and vibration analysis, in combination with actual engineering.

Although there have been studies of a cable-stayed bridge with leaning tower, the mechanical properties of the main tower of a prestressed concrete cable-stayed bridge have not been studied. In a zigzag bridge tower, the zigzag geometrical characteristics of the zigzag line and the overall structural effect of the vertices cause a different deformation resistance of the zigzag bridge tower compared to a straight or a leaning tower. For a fold-line tower, the axial force's transmission direction changes at the fold area, generating a large amount of tension force. The use of a steel structure in the main tower can easily solve the stress problem at the corners, but the stress will be very complicated for a concrete main tower.

In this work, the mechanical properties of a concrete fold-line tower were analyzed by numerical analysis and experimental study on the key parts of the cables and the tower anchorage area. Firstly, six symmetrical load loading tests were carried out on the test section of the broken-line bridge tower at the bridge completion stage to determine the stress of the test section of the main tower under constant load and live load. The results indicated that the corner of the main tower should be the focus of the design control, as there is a serious stress concentration in this part. Based on the stress characteristics of the concrete broken-line tower, stiffening plates should be added to the section of the broken-line tower. With no stiffening plate, the transverse force will be produced as the result of the axial force of the mid-span and side-span tower walls at the corner. The component force causes the out-of-plane bending of the second tower wall, and this effect increases the stress gradient of the mid-span side tower wall section. After installation of a stiffening plate at the corner, the stress concentration of the corner section decreases. Although the effect of the stiffening plate to reduce the maximum compressive stress of the corner section is limited, the stress distribution diagram revealed that the use of the stiffening plate eliminates the external bending of the mid-span tower wall, so that the stress distribution of the corner section of the main tower conforms to the assumption of a flat section. After installation of the stiffener, vertical tensile stress appears at the inner periphery of the stiffener at the corner. To deal with this, the size of the axillary angle of the stiffener should be appropriately increased during design, and the vertical main tensile reinforcement and surface anticrack reinforcement of the inner periphery of the stiffener should be appropriately strengthened. The results of this work should provide guidance for future design efforts.

\section{Research Background}

A single cable plane cable-stayed bridge was the focus of this study. The main bridge's length is $420 \mathrm{~m}$, the side span is $89 \mathrm{~m}$, the middle span is $242 \mathrm{~m}$, the main beam material is C50 concrete, and the section is single box with three rooms. A total of 120 galvanized high-strength steel wires are used in the bridge, with specifications of 151- $\$ 7,211-\Phi 7,241-\Phi 7$, and 301-Ф7, as shown in Figure 1.

\section{Model Design and Production}

3.1. Design Model. A structural model was constructed based on three theorems of similarity theory to obtain results close to the objective reality [11-15]. The section stiffness of the Fumin Bridge test model is similar to the bridge prototype. The test model is geometrically similar to the bridge prototype and uses as large a scale as possible. The load of the test model is proportionally reduced according to the actual load ratio. The materials of the bridge testing model and the prototype are similar. The test model has the same boundary conditions as the real bridge.

The model test of cable-stayed bridge requires certain site conditions, loading conditions, and test costs. Selecting the optimal geometric scale is the primary problem to be solved in the model design process. Large-scale models are easy to make and experimental data are easy to collect but are costly and labor-intensive and require large test sites and loading equipment. A small-scale model requires only a lightweight load, but it is relatively difficult to build or equip with test instruments and the measurement error is relatively large. It is necessary to weigh various test conditions and requirements before selecting the most appropriate scale for model making. Through comprehensive consideration, the optimal geometric scaling ratio for the model in this study was determined to be $1: 40$, and the length of the cablestayed bridge model was $10.5 \mathrm{~m}$.

3.1.1. Box Girder Design. According to the geometric similarity, the size of the box girder section model remains basically unchanged and the wall thickness of the box girder is halved to ensure similar section area and the moment of inertia. Additionally, the section similarity deviation is controlled within the allowable range. The error of modulus only affects the section stress, so the accurate similarity ratio of the strain and stress of the model and prototype can be calculated under corresponding working conditions.

There are 19 sections in the box girder of the testing model, which can be spliced section-by-section according to the construction process. Dead load compensation is achieved by hanging heavy objects directly at the hanging point, and the construction load and live load are achieved by adding heavy loads to the bridge deck. The full bridge model is shown in Figure 2.

3.1.2. Stay Cable Design. The stay cable of the model is made of high-strength steel wires, with an elastic modulus ratio that is equal to 1 . 


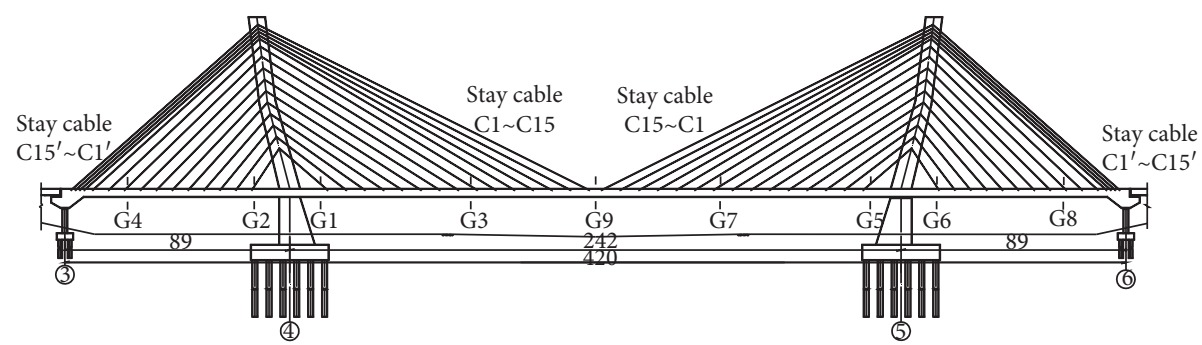

(a)

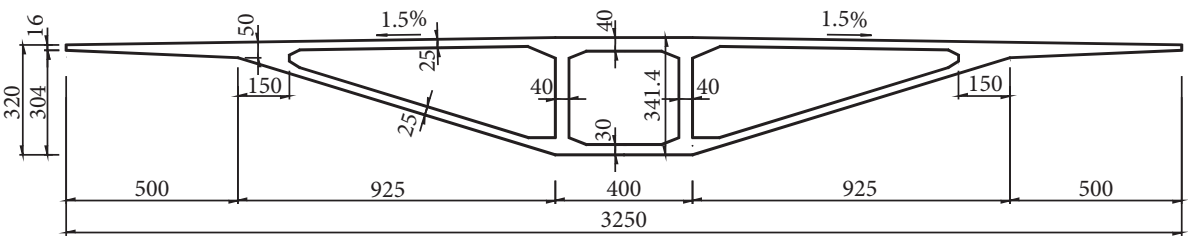

(b)

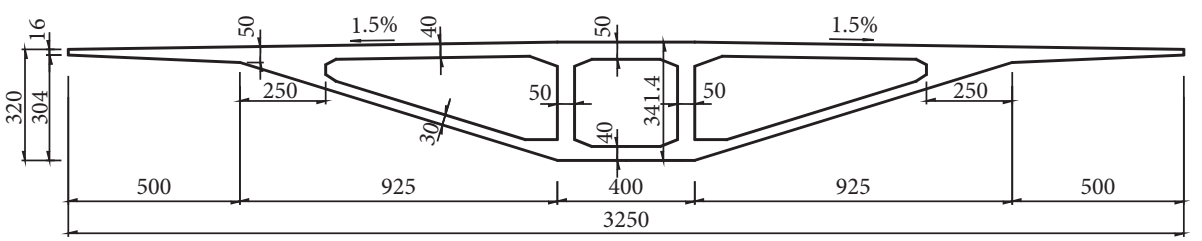

(c)

Figure 1: Structural drawing of bridge (unit: $\mathrm{cm}$ ). (a) Schematic of main bridge. (b) Cross section of mid-span girder. (c) Cross section of side-span girder.

The box girder and stay cable are connected by screw thread, allowing easy adjustment of the stay cables. A vibrating wire type load cell is installed at the joint to measure the cable force of the stay cable. The self-weight of the stay cable significantly affects the deformation of the stay cable. To accurately reflect the mechanical characteristics of the structural nonlinearity, load compensation is performed for the dead weight of the cable and an additional mass method is also adopted.

3.1.3. Main Tower Design. The external contour dimensions of the main tower section remain basically unchanged, maintaining a similar relationship between the moment of inertia and the cross-sectional area.

The main tower of the bridge is a broken line, and the dead load of the main tower not only produces the stress of the tower body but also produces the bending moment of the tower body. This will affect the entire structural system of the cable-stayed bridge internal force state, making it necessary to carry out dead load compensation for the main tower.

3.2. Model Construction and Installation. A special vibrating wire sensor is used to simulate the stay cable sensor and must be individually calibrated before installation to ensure long-term stability, accuracy, and reliability.

In order to simulate the construction process, the box girder is installed in subsections, according to construction requirements. Once pier \#5 is set as a temporary pier, the load sensor is installed to measure the counter force of the temporary support under the action of construction load. The model installation is shown in Figure 3.

\subsection{Loading System and Dead Load Compensation}

3.3.1. Dead Load Compensation of the Main Tower. The dead load compensation of the main tower is carried out in two sections as concentrated load that is applied by the lever system. The upper segment load of the main tower is applied to the center of gravity on the upper segment of main tower and the lower segment load is compensated according to the similar bending moment of the tower root. This guarantees that the tower root section and main tower bending corner section load effect are similar. The upper segment is compensated by $837.1 \mathrm{~kg}$, and the lower segment is compensated by $620 \mathrm{~kg}$.

3.3.2. Load Compensation of the Main Girder. The load compensation of the main girder is performed as concentrated load to the transverse diaphragm. The intermediate span standard segment, intermediate span tower root segment, side-span standard segment, and the intermediate span tower root segment are $260.3 \mathrm{~kg}, 385.3 \mathrm{~kg}, 277.2 \mathrm{~kg}$, and $335.8 \mathrm{~kg}$, respectively. The second stage dead load compensation for the lifting points are $65.0 \mathrm{~kg}$ for the side span and $76.3 \mathrm{~kg}$ for the middle span. 


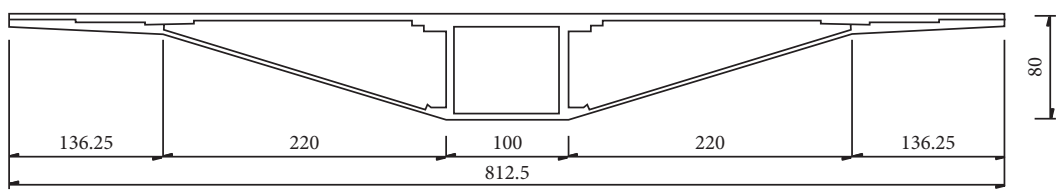

(a)

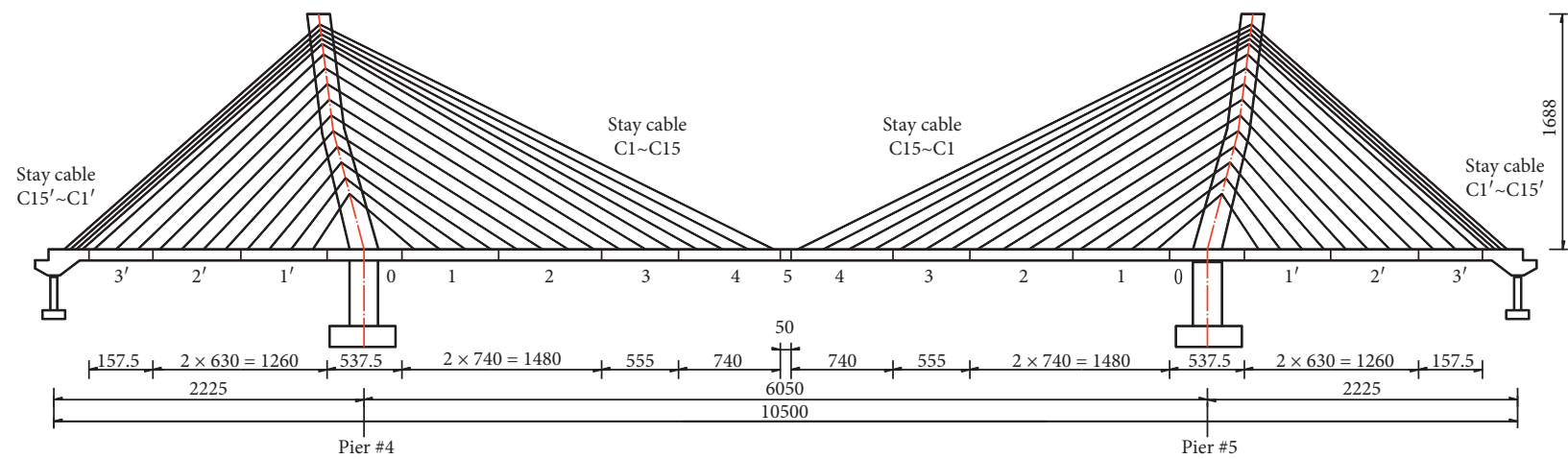

(b)

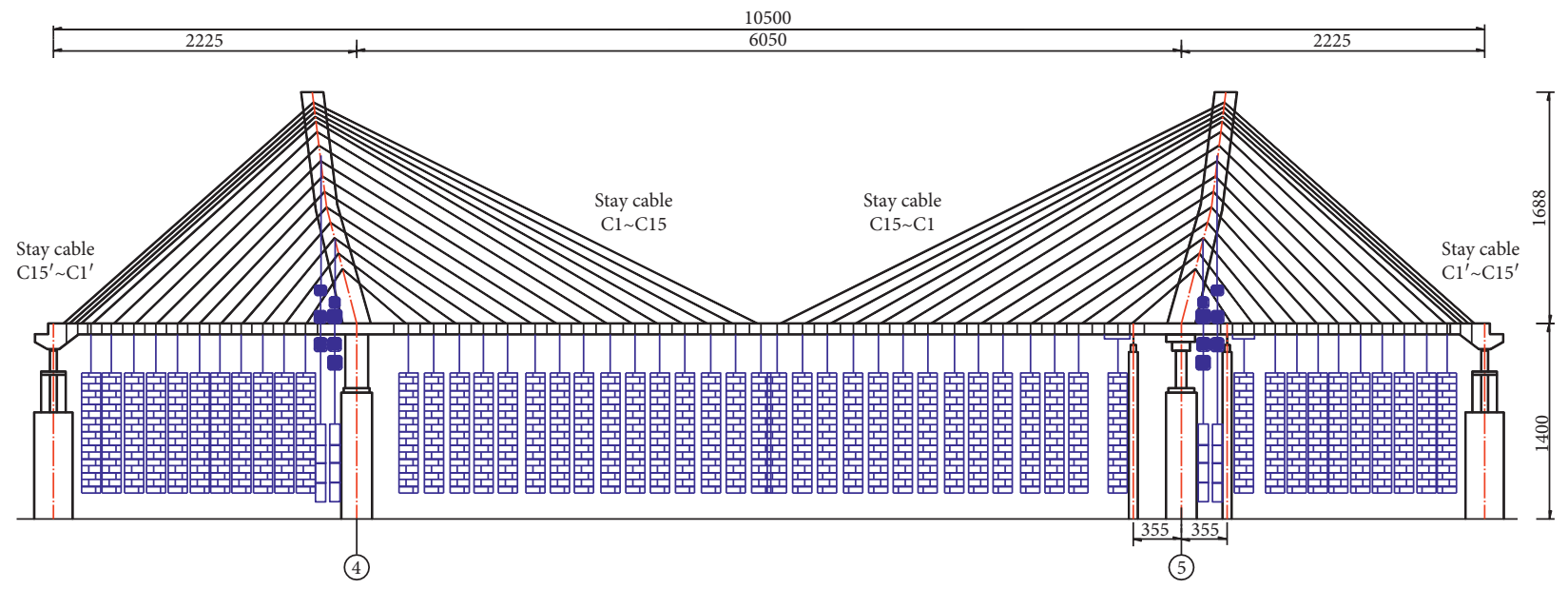

(c)

Figure 2: General arrangement drawing of model (unit: $\mathrm{cm}$ ). (a) Mid-span section diagram. (b) Block diagram. (c) Temporary support and loading diagram.

\section{Test Load Working Conditions and Test Contents}

In the actual construction process of the original bridge, the stay cable and the box girder are installed, and the stay cable, the box girder, and the main tower are gradually compensated for dead load. Then the stay cable is tensioned and the cable is adjusted [16-19].

In the construction stage of the model, the construction load and the stress of the girder section must be simulated under the working condition of mid-span closure.

4.1. Test System and Measuring Point Arrangement. The model testing system includes the following: a support reaction force testing system, a dead load testing system, a stress testing system, a displacement testing system, and a cable force testing system.
Each fulcrum is equipped with a calibrated strain tester and a load cell as part of the reaction force test system. The cable force test system consists of a calibrated special frequency tester and a steel string load cell. The section and measuring point design are shown in Figures 4 and 5 .

4.2. Service Stage Condition. The service stage test included the following six symmetrical load cases for the tower column test section: (1) working condition 1, loading the positive bending moment of the T1 section; (2) working condition 2, loading the positive bending moment of the T21 section; (3) working condition 3, loading the positive bending moment of the T3 section; (4) working condition 4, negative bending moment loading on T3 section; (5) working condition 5 , loading positive bending moment of T4-1 section; and (6) working condition 6 , loading negative bending moment of T4-1 section. 


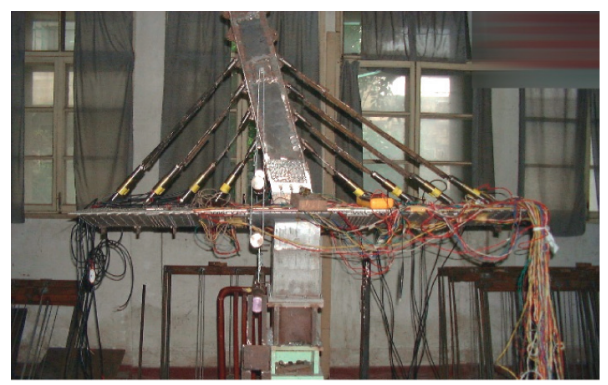

(a)

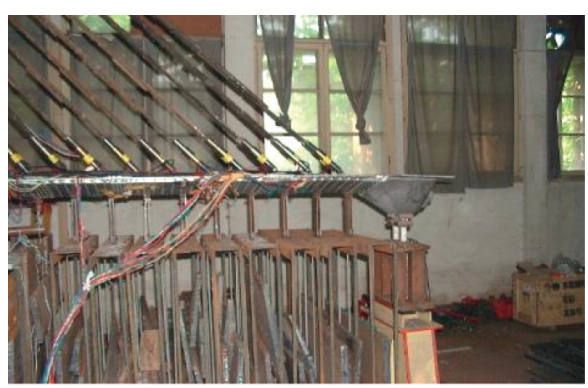

(b)

FIGURE 3: Installing the model. (a) Installing four pairs of stay cables at pier \#4. (b) Closure of side span of pier \#5.

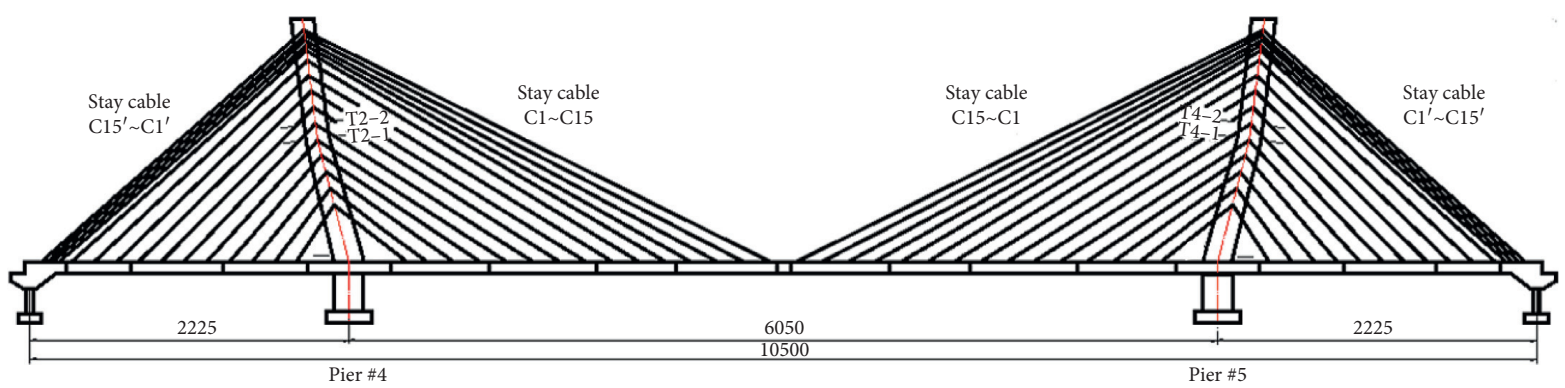

Figure 4: Diagram of testing section arrangement about girder (unit: $\mathrm{cm}$ ).
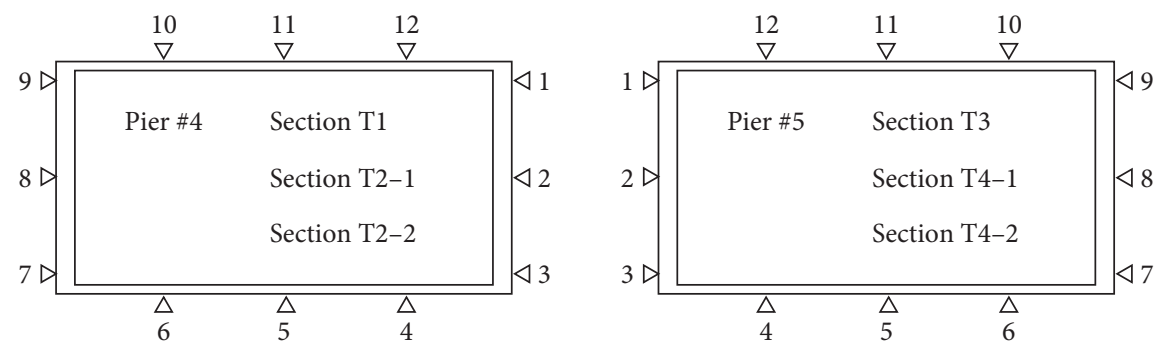

FIGURE 5: Layout diagram of the stress measuring points of the tower column test section.

4.3. Analysis of Test Results. Working conditions 1 to 6 were separately applied to the maximum bending moment of tower columns T1 to T4. The stresses of the test sections of the tower column are shown in Tables 1 and 2, and the stress distributions are shown in Figures 6 and 7.

For working condition 1, the maximum positive moment of the T1 section of pier \#4 is loaded. Under the action of live load, the side tower wall of the side span is in tension, with a measured maximum tensile stress of $0.99 \mathrm{MPa}$ and an average value of $0.88 \mathrm{MPa}$. The side tower wall of the middle span is compressed, and the measured maximum compressive stress is $-2.22 \mathrm{MPa}$, with an average value of $-1.22 \mathrm{MPa}$. The theoretically calculated stresses of the side tower walls of the side and the mid-span sections are 1.46 $\mathrm{MPa}$ and $-2.61 \mathrm{MPa}$, respectively.

In working condition 2 , the maximum positive moment of the T2-1 section of pier \#4 is loaded. Under the action of live load, the maximum tensile stress measured of the side tower wall of the side-span section is $0.67 \mathrm{MPa}$, with an average value of $0.62 \mathrm{MPa}$. The measured maximum compressive stress of the side tower wall of the middle span is $-21.13 \mathrm{MPa}$, and the average value is $-1.91 \mathrm{MPa}$. The theoretical calculated stresses of the side tower walls of the sidespan and the mid-span sections are $0.61 \mathrm{MPa}$ and -1.41 MPa, respectively. Comparison shows that the measured side-span side stress values are close to the calculated values, but the measured stress values of the mid-span side are larger than the calculated values. The ratio of the measured maximum value to the theoretically calculated average value is 1.51 .

In working condition 2 , the T2-2 section of pier \#4 is loaded, with measured maximum tensile stress of the side tower wall of the side span of $0.64 \mathrm{MPa}$, with an average value of $0.42 \mathrm{MPa}$. The measured maximum compressive stress of the side tower wall of the middle span is $-1.43 \mathrm{MPa}$, and the average value is $-1.27 \mathrm{MPa}$. The theoretical calculated stresses of the side tower walls of the side-span and the mid-span sections are $0.41 \mathrm{MPa}$ and $-1.22 \mathrm{MPa}$, respectively. The measured stress value is close to the calculated value. 
TABle 1: Test section stress of no. 4 tower column (unit: MPa).

\begin{tabular}{|c|c|c|c|c|}
\hline Part & Point number & $\begin{array}{c}\mathrm{T} 1 \\
\text { Working condition } 1\end{array}$ & $\begin{array}{c}\text { T2-1 } \\
\text { Working condition } 2\end{array}$ & $\begin{array}{c}\text { T2-2 } \\
\text { Working condition } 2\end{array}$ \\
\hline \multirow{5}{*}{ Mid-span side } & 1 & -1.91 & -1.77 & -1.19 \\
\hline & 2 & -2.32 & -2.13 & -1.43 \\
\hline & 3 & -2.13 & -1.83 & -1.19 \\
\hline & Average value & -2.12 & -1.91 & -1.27 \\
\hline & Theoretical value & -2.61 & -1.41 & -1.22 \\
\hline \multirow{3}{*}{ Upstream side } & 4 & -1.18 & -1.59 & -0.95 \\
\hline & 5 & -1.08 & -0.64 & -0.32 \\
\hline & 6 & -0.25 & 0.00 & 0.00 \\
\hline \multirow{5}{*}{ Side-span side } & 7 & 0.80 & 0.64 & 0.32 \\
\hline & 8 & 0.99 & 0.67 & 0.64 \\
\hline & 9 & 0.86 & 0.54 & 0.32 \\
\hline & Average value & 0.88 & 0.62 & 0.42 \\
\hline & Theoretical value & 1.46 & 0.61 & 0.41 \\
\hline \multirow{3}{*}{ Downstream side } & 10 & -0.25 & 0.06 & 0.06 \\
\hline & 11 & -1.08 & -0.38 & -0.32 \\
\hline & 12 & -1.59 & -0.93 & -0.64 \\
\hline
\end{tabular}

TABle 2: Column section test section stress (unit: MPa).

\begin{tabular}{|c|c|c|c|c|c|c|c|}
\hline \multirow[b]{2}{*}{ Part } & \multirow[b]{2}{*}{$\begin{array}{l}\text { Measuring point } \\
\text { number }\end{array}$} & \multicolumn{2}{|c|}{ T3 } & \multicolumn{2}{|c|}{ T4-1 } & \multicolumn{2}{|c|}{$\mathrm{T} 4-2$} \\
\hline & & $\begin{array}{c}\text { Working } \\
\text { condition } 3\end{array}$ & $\begin{array}{c}\text { Working } \\
\text { condition } 4\end{array}$ & $\begin{array}{c}\text { Working } \\
\text { condition } 5\end{array}$ & $\begin{array}{c}\text { Working } \\
\text { condition } 6\end{array}$ & $\begin{array}{l}\text { Working } \\
\text { condition } 5\end{array}$ & $\begin{array}{c}\text { Working } \\
\text { condition } 6\end{array}$ \\
\hline \multirow{5}{*}{ Mid-span side } & 1 & -0.80 & 0.35 & -1.62 & 0.95 & -1.00 & 0.80 \\
\hline & 2 & -0.54 & 0.25 & -1.75 & 1.08 & -1.23 & 1.15 \\
\hline & 3 & -1.02 & 0.38 & -1.69 & 1.24 & -1.02 & 0.95 \\
\hline & Average value & -0.78 & 0.73 & -1.69 & 1.09 & -1.08 & 0.97 \\
\hline & Theoretical value & -0.90 & -0.54 & -1.18 & 1.00 & -1.06 & 0.95 \\
\hline \multirow{3}{*}{ Upstream side } & 4 & -0.51 & -1.18 & - & - & -0.54 & 0.35 \\
\hline & 5 & -0.35 & -1.27 & 0.25 & -0.48 & -0.06 & -0.13 \\
\hline & 6 & 0.06 & -1.30 & 0.89 & -1.37 & 0.54 & -0.92 \\
\hline \multirow{5}{*}{ Side flank } & 7 & 0.60 & -1.53 & 1.15 & -1.34 & 1.05 & -1.83 \\
\hline & 8 & 0.64 & -1.72 & 1.24 & -1.58 & 1.18 & -2.10 \\
\hline & 9 & 0.64 & -1.52 & 1.40 & -1.83 & 0.95 & -1.67 \\
\hline & Average value & 0.63 & -1.59 & 1.26 & -1.58 & 1.06 & -1.87 \\
\hline & Theoretical value & 0.78 & -0.89 & 1.20 & -1.69 & 1.09 & -1.64 \\
\hline \multirow{3}{*}{$\begin{array}{l}\text { Downstream } \\
\text { side }\end{array}$} & 10 & -0.06 & -0.57 & 0.60 & -1.02 & 0.57 & -1.27 \\
\hline & 11 & -0.29 & -0.16 & 0.19 & -0.51 & - & - \\
\hline & 12 & -0.38 & 0.54 & -0.76 & 0.22 & -0.80 & 0.19 \\
\hline
\end{tabular}

In working condition 3 , the maximum positive moment of the T3 section of pier \#5 is loaded. With live load, the maximum tensile stress measured of the side tower wall of the side span is $0.64 \mathrm{MPa}$, with an average value of $0.63 \mathrm{MPa}$. The measured maximum compressive stress of the side tower wall of the middle span is $-1.02 \mathrm{MPa}$, and the average value is $-0.78 \mathrm{MPa}$. The theoretical calculated stress values of the side tower walls of the side-span and the mid-span sections are $0.78 \mathrm{MPa}$ and $-0.90 \mathrm{MPa}$, respectively. Comparison shows that the measured stress average is less than the theoretically calculated stress.

In working condition 4 , the maximum negative moment of the T3 section of pier \# 5 is loaded. Under the action of live load, the maximum compressive stress measured of the side tower wall of the side span is $-1.72 \mathrm{MPa}$, with an average value of $-1.52 \mathrm{MPa}$. The measured maximum tensile stress of the side tower wall of the middle span is $0.54 \mathrm{MPa}$ and the average value is $0.38 \mathrm{MPa}$. The theoretical calculated stresses of the side tower walls of the side-span and the mid-span sections are $-1.59 \mathrm{MPa}$ and $0.73 \mathrm{MPa}$, respectively. The measured stress values were lower than the theoretically calculated stress values.

For working condition 5, the maximum positive moment of the T4-1 section of pier \#5 was loaded. Under the action of live load, the maximum tensile stress measured of the side tower wall of the side span is $1.40 \mathrm{MPa}$, with an average value of $1.26 \mathrm{MPa}$. The measured maximum compressive stress of the side tower wall of the middle span is $-1.75 \mathrm{MPa}$, and the average value is $-1.69 \mathrm{MPa}$. The theoretical calculated stress values of the side tower walls of the side-span and the mid-span sections are $1.20 \mathrm{MPa}$ and $-1.18 \mathrm{MPa}$, respectively. Comparison reveals that the 


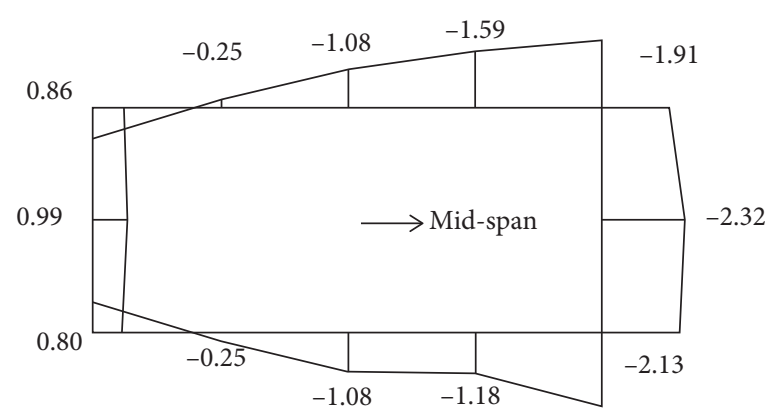

(a)

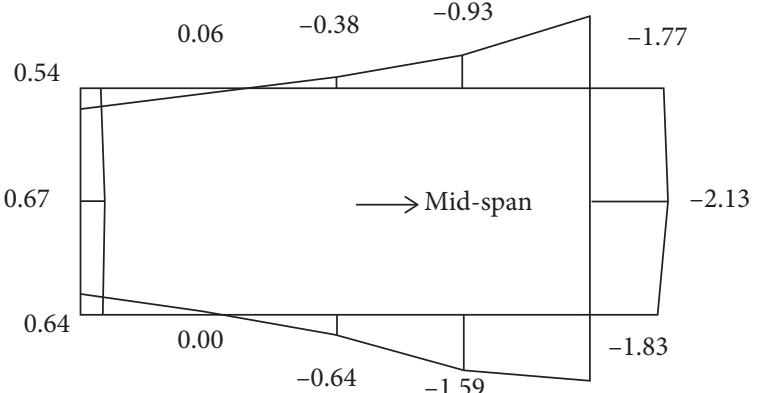

(b)

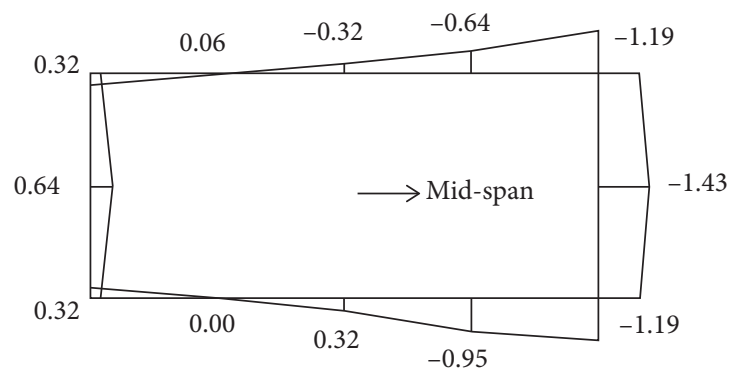

(c)

FIgURE 6: Stress distribution diagram of section no. 4 tower column under live load (unit: MPa). (a) Working condition 1, T1 section's positive moment loading stress diagram. (b) Working condition 2, T2-1 section's positive moment loading stress diagram. (c) Working condition 2, T2-2 section's positive moment loading stress diagram.

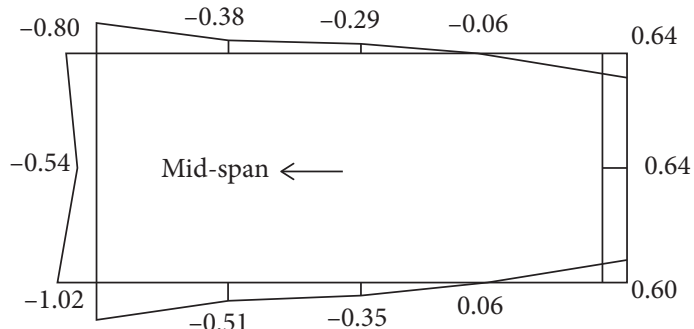

(a)

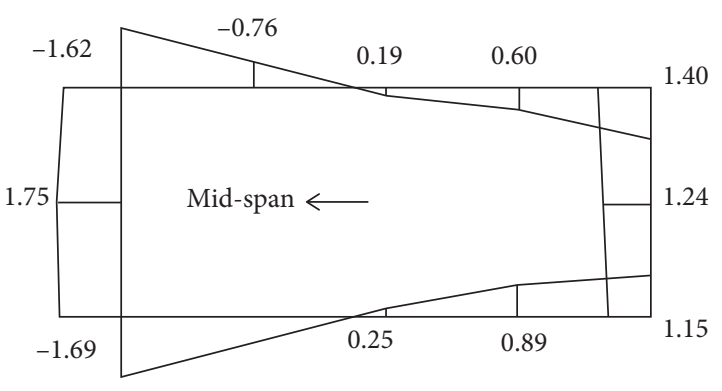

(c)

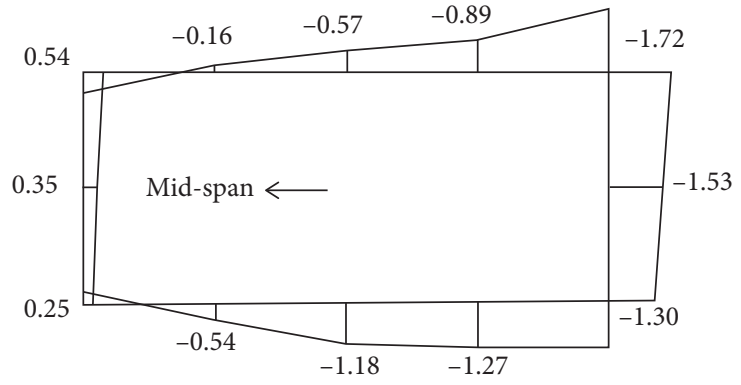

(b)

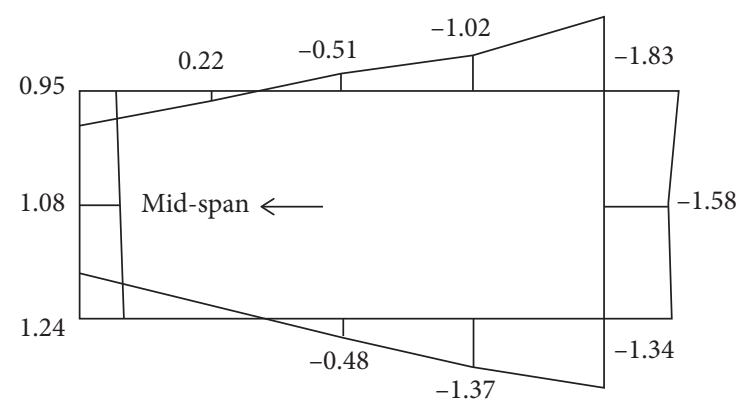

(d)

FIgURE 7: Continued. 


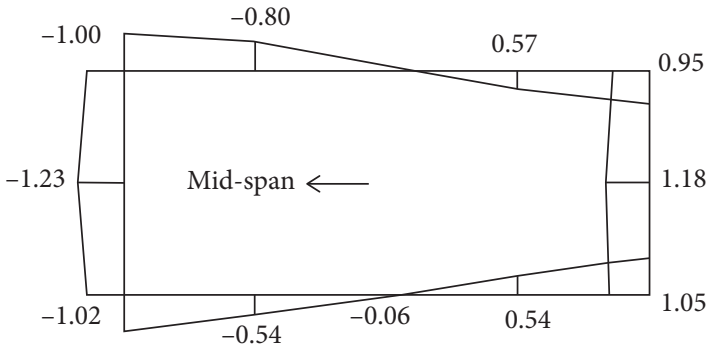

(e)

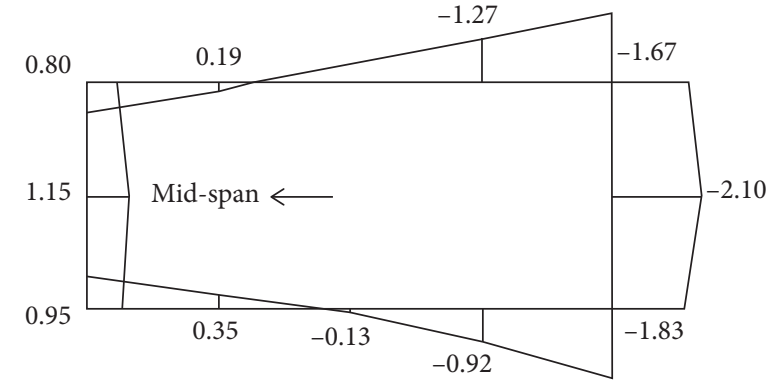

(f)

Figure 7: Stress distribution diagram of section no. 5 tower column under live load (unit: MPa). (a) Working condition 3 , T3 section's positive moment loading stress diagram. (b) Working condition 4, T3 section's negative moment loading stress diagram. (c) Working condition 5, T4-1 section's positive moment loading stress diagram. (d) Working condition 6, T4-1 section's negative moment loading stress diagram. (e) Working condition 5, T4-2 section's positive moment loading stress diagram. (f) Working condition 6, T4-2 section's negative moment loading stress diagram.

measured side-span side stresses values are close to the calculated values, with measured stress values of the midspan side that are larger than the calculated values. The ratio of the measured maximum value to the theoretically calculated average value is 1.48 , which is close to the mid-point stress concentration factor of 1.60 calculated for the section of the side tower wall of the middle span of the model tower column in the construction stage.

For working condition 6 , the maximum negative moment of the T4-1 section of pier \#5 was loaded. Under the action of live load, the maximum compressive stress measured for the side tower wall of the side span is $-1.83 \mathrm{MPa}$, and the average value is $-1.58 \mathrm{MPa}$. The maximum tensile stress measured of the side tower wall of the middle span is 1.24 MPa, with an average value of 1.09 MPa. The theoretical calculated stresses of the side tower walls of the side-span and the mid-span sections are $-1.69 \mathrm{MPa}$ and $1.00 \mathrm{MPa}$, respectively. Comparison reveals that the measured stress average is close to the calculated value.

Under working condition 5, testing the T4-2 section of pier \#5, the maximum tensile stress measured of the side tower wall of the side span is $1.18 \mathrm{MPa}$, and the average value is $1.06 \mathrm{MPa}$. The measured maximum compressive stress of the side tower wall of the middle span is $-1.23 \mathrm{MPa}$, and the average value is $-1.08 \mathrm{MPa}$. The theoretical calculated stresses of the side tower walls of the side-span and the midspan sections are $1.09 \mathrm{MPa}$ and $-1.06 \mathrm{MPa}$, respectively. Comparison reveals that the measured stress is close to the calculated value, consistent with section T2-2 of pier \#4.

For working condition 6, testing the T4-2 section of pier $\# 5$, the measured maximum compressive stress of the side tower wall of the side span is $-2.10 \mathrm{MPa}$, with an average value of $-1.87 \mathrm{MPa}$. The maximum tensile stress measured for the side tower wall of the middle span is $1.15 \mathrm{MPa}$, with an average value of $0.97 \mathrm{MPa}$. The theoretical calculated stress values of the side tower walls of the side-span and the mid-span sections are $-1.87 \mathrm{MPa}$ and $0.95 \mathrm{MPa}$, respectively. Comparison reveals that the measured mid-span side stress values are close to the calculated values, and the measured stress values of the side-span side are larger than the calculated values.
Comparison of the $\mathrm{T} 1$ and $\mathrm{T} 3$ sections and the bending corner sections T2-1 and T4-1 of the main tower roots of pier \#4 and pier \#5 shows that, due to the different structural systems, the bending stress of pier \#4 is larger than that of pier \#5.

After superimposing the maximum stress of the midspan side and side-span side tower (pier) wall measurement points in each test section and the measured stress in the construction stage, the maximum stresses of the mid-span side and side-span side towers walls (piers) in each test section were calculated and are summarized in Table 3.

It can be seen from Table 3 that, under the action of live load, sections $\mathrm{T} 1$ and $\mathrm{T} 3$ at the corner of the tower root show tensile stress on the side-span side, and sections T2-1 and T4-1 at the corner of the tower show more tensile stress. Under the combined action of constant load and live load, the measured stress values of the cross section T2-1 on the mid-span side and the side-span side are quite different, which can reach $17.53 \mathrm{MPa}$. Owing to the angle of the main tower, the direction of the axial force transmission changes at the angle of the main tower, generating a large horizontal pulling force.

\section{Finite Element Analysis}

According to the mechanical characteristics of the main tower section T2-1 in the model test, the finite element solid analysis of the corner part of the main tower was carried out, the results with and without stiffeners at the corners were compared, and the improvement of the mechanical properties of the main tower by setting stiffening plates was analyzed.

5.1. Finite Element Model Calculation Assumption. In the finite element model calculation, the following assumptions are made: (1) The structure of the tower body is a homogeneous elastomer, and the material properties of the structure are expressed according to an elastic modulus of $3.45 \times 104 \mathrm{MPa}$ and a Poisson's ratio of 0.1667 [20, 21]. (2) The main load is the tensile force of the cable and the 
TABLE 3: Summary of maximum stress of each test section of main tower (unit: MPa).

\begin{tabular}{|c|c|c|c|c|c|c|}
\hline \multirow{2}{*}{ Section } & \multicolumn{2}{|c|}{ Dead load effect } & \multicolumn{2}{|c|}{ Live load effect } & \multicolumn{2}{|c|}{ Dead load + live load } \\
\hline & Mid-span side & Side-span side & Mid-span side & Side-span side & Mid-span side & Side-span side \\
\hline $\mathrm{T} 1$ & -9.45 & -16.83 & -2.32 & 0.99 & -11.77 & -15.84 \\
\hline $\mathrm{T} 2-1$ & -21.35 & -6.62 & -2.13 & 0.67 & -23.48 & -5.95 \\
\hline $\mathrm{T} 2-2$ & -14.32 & -6.99 & -1.43 & 0.64 & -15.75 & -6.35 \\
\hline $\mathrm{T} 3$ & -13.47 & -14.76 & -1.02 & 0.64 & -14.49 & -14.12 \\
\hline T4-1 & -16.10 & -9.07 & -1.75 & 1.40 & -17.85 & -7.67 \\
\hline $\mathrm{T} 4-2$ & -13.24 & -9.36 & -1.23 & 1.18 & -14.47 & -8.18 \\
\hline
\end{tabular}

pressure of prestressed reinforcement in the horizontal direction. This is added in stages according to the external load mode [22-24].

Prestress treatment is a challenge of 3D solid analysis, and the accuracy of its simulation is the key to the success of such structural analysis. There are generally three ways to add prestress in the finite element calculation: (1) Add prestress directly to the unit. (2) Load prestress directly to the key point. (3) Simulate prestress by temperature change [25-27].

The model analysis focuses on the overall stress characteristics of the main tower, so, to simplify the analysis, the prestress of the model is directly loaded to the key points. Additionally, the prestressing loss considers the prestress loss, calculating $80 \%$ of the tension tonnage value.

5.2. Selection of Calculation Parameters. In the analysis, the units are $\mathrm{kN}, \mathrm{m}$, and $\mathrm{kPa}$; the material is C50 concrete; the bulk density is $\rho=26 \mathrm{kN} / \mathrm{m}^{3}$; and Poisson's ratio $\gamma=0.1667$. The elastic modulus of the prestressed tendons is $E=2.03 \times 105 \mathrm{MPa}$, and Poisson's ratio is 0.3 .

\subsection{Analysis of Stress Calculation Results When No Stiffener Is} Installed at Bending Corner. The diagram in Figure 8 shows the principal compressive stress distribution of the bending corner portion (with no stiffening plate at the bending corner), showing obvious stress concentration. The maximum compressive stress is $-19.80 \mathrm{MPa}$. The range of the high stress zone is small. At $0.6 \mathrm{~m}$ above the bending corner section, the maximum compressive stress is $-17.50 \mathrm{MPa}$.

The diagram in Figure 9 shows the stress distribution of the bending corner section. The diagram in Figure 10 shows the stress distribution of the $0.6 \mathrm{~m}$ section above the bending corner section. Comparison of the two figures reveals that, due to the fact that the bending corner section has no stiffening plate, the axial force of the side tower walls of the middle span and the side span will generate lateral component forces at the bending corner, resulting in out-ofplane bending of the tower wall.

\subsection{Analysis of Stress Calculation Results with a Stiffening} Plate at Bending Corner. To improve the stress distribution at the bending corners, a stiffening plate was added at the bending corner of the main tower to perform stress analysis. The structural diagram of the stiffening plate is shown in Figures 11 and 12.

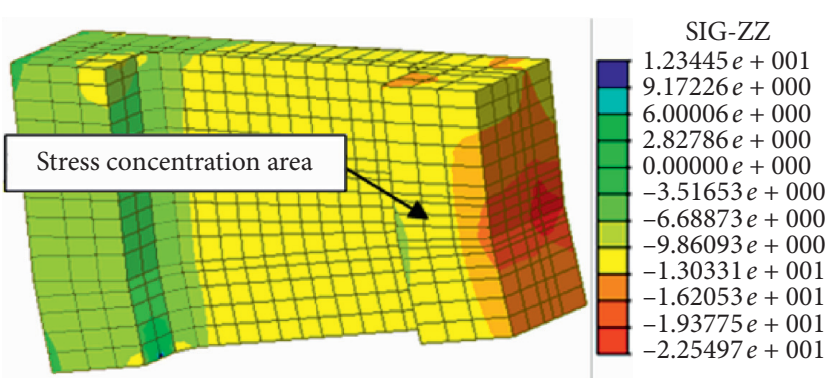

Figure 8: Principal compressive stress of bevel section (MPa).

The diagram in Figure 13 shows the bending corner portion stress distribution after the stiffening plate is added to the bending corner section. The maximum compressive stress of the corner section is $-18.97 \mathrm{MPa}$, and the maximum compressive stress of the $0.6 \mathrm{~m}$ section is $-17.00 \mathrm{MPa}$. Both stress values are lower than those in the absence of a stiffening plate. The effect of the stiffening plate to reduce the maximum compressive stress of the corner section is limited, but the stress distribution diagram shows that the use of the stiffening plate eliminates the out-of-plane bending phenomenon of the side tower wall of the middle span, causing the stress distribution of the main tower angle section to conform to the flat section assumption. The vertical tensile stress appears in the inner periphery of the stiffening plate at the bending corner part, with a maximum value of $1.35 \mathrm{MPa}$. The results indicate that the side wall of the main tower is subjected to large vertical compressive stress, and the concrete three-way medium is vertically squeezed to cause lateral expansion deformation. This is similar to the "stress vortex" produced by the main stress flow at the abrupt change of channel section. In the cases of the main tower section T2-1 without stiffening plates, with stiffening plates, or model tests, the stresses at each measuring point are summarized and compared. The data in Table 4 shows that, after the above-mentioned concrete broken-line bridge tower is provided with the above structure, the phenomenon of stress concentration at the corner of the main tower is significantly reduced, which effectively improves the mechanical characteristics of the concrete broken-line bridge tower. If no measures are taken, the resulting local tension will produce cracks. To avoid cracking, the angle of the stiffening plate corner should be increased, and the configuration of the vertical main tensile steel bar and the surface anticracking steel mesh inside the stiffening plate should be appropriately strengthened. 


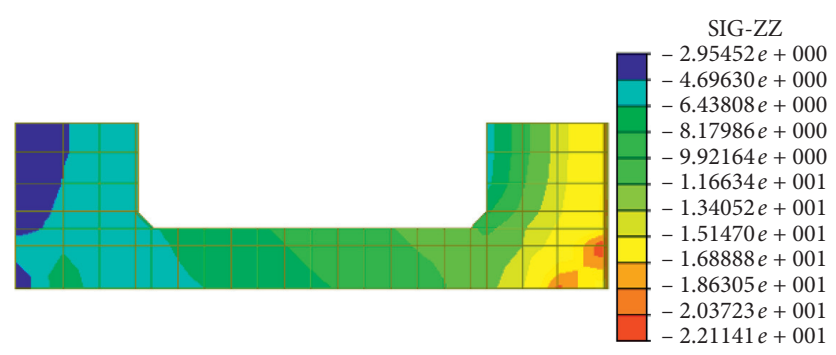

Figure 9: Normal stress of bevel section (MPa).

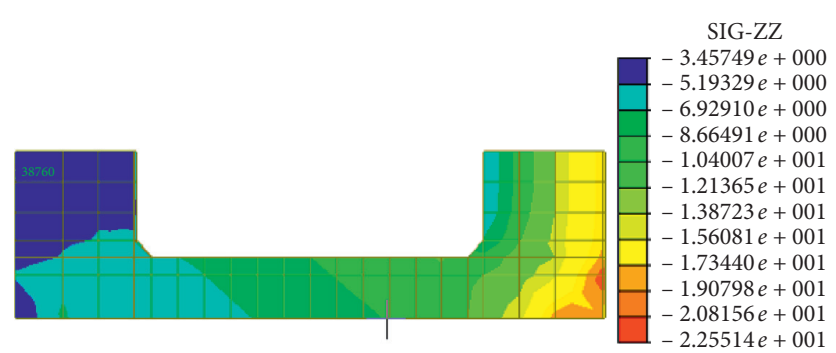

Figure 10: Normal stress of bevel section above $0.6 \mathrm{~m}(\mathrm{MPa})$.

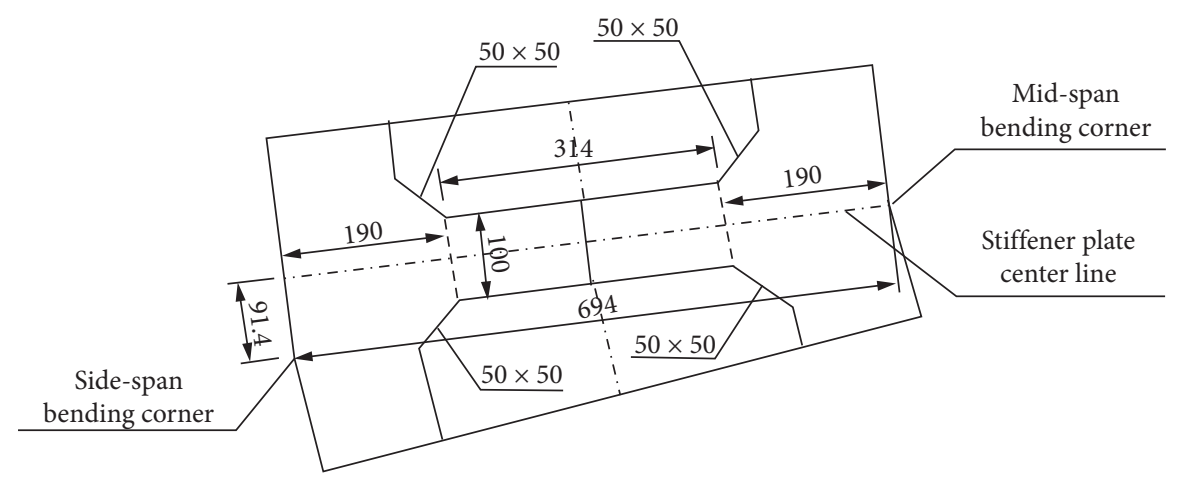

FIGURE 11: Elevation of a stiffening plate for the bending corner of the main tower.

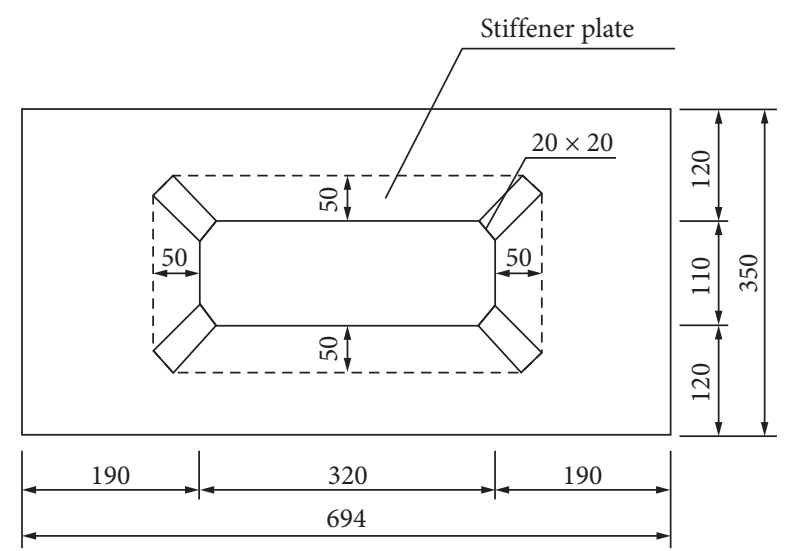

FIGURE 12: Plan incorporating a stiffening plate of the bending corner of the main tower.

The maximum compressive stress of the concrete calculated above is a local phenomenon, and the high stress range is small. In addition, concrete will undergo a certain creep under the action of high-pressure stress, so that the stress will be redistributed, resulting in a certain decrease in high stress. Overall, it can be concluded that the concrete compressive stress of the main tower bending corner section meets the design specifications. 


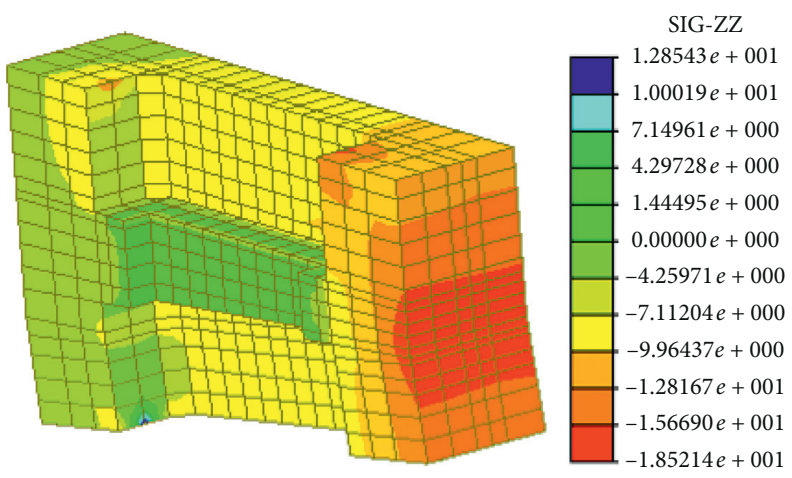

FIgURE 13: Normal stress distribution diagram after setting of the stiffening plate at the bending corner of the main tower (MPa).

TABLE 4: Comparison table of stresses at each measuring point of corner section T2-1 of main tower (unit: MPa).

\begin{tabular}{lcccc}
\hline \multirow{2}{*}{ Part } & Measuring point number & \multicolumn{2}{c}{ Dead load + live load } \\
& & Without stiffener & With stiffener & Measured value of model test \\
\hline \multirow{3}{*}{ Mid-span side } & 1 & -14.22 & -13.35 & -15.16 \\
& 2 & -21.35 & -19.89 & -23.48 \\
& 3 & -13.94 & -12.98 & -14.59 \\
Upstream side & Average value & -16.50 & -15.41 & -16.41 \\
& 4 & -15.94 & -14.11 & -14.05 \\
Side flank & 5 & -14.35 & -13.89 & -8.56 \\
& 6 & -7.03 & -6.18 & -5.01 \\
& 7 & -5.12 & -5.01 & -4.98 \\
Downstream & 8 & -3.82 & -3.56 & -5.95 \\
& 9 & -6.62 & -5.91 & -5.31 \\
\hline
\end{tabular}

\section{Conclusion}

Fumin Bridge of Shenyang City was studied and the stress characteristics and structural design of the box-shaped main tower of the prestressed concrete folding line tower are described. Spatial finite element theory was used to analyze the stress characteristics of the control section of the polygonal line tower. The main conclusions are as follows:

(1) The bending corner of the main tower is the key part of design control. There is a serious stress concentration in this part, with a small range of high stress area.

(2) When the bending corner section lacks a stiffening plate, the axial force of the side tower walls of the middle span and the side span will generate lateral component forces at the bending corner, resulting in out-of-plane bending of the two tower walls. This can have a great influence on the side tower wall of the middle span, increasing the stress gradient of the cross section of the side tower wall.

(3) After the stiffening plate is placed at the corner, the stress concentration factor of the bending corner section decreases. Although there is a limited effect of the stiffening plate to reduce the maximum compressive stress of the bending corner section, as shown in the stress distribution diagram, the use of the stiffening plate eliminates the out-of-plane bending phenomenon of the side tower wall of the middle span, making the stress distribution of the main tower angle section conform to the flat section assumption. This is because the vertical tensile stress appears in the inner periphery of the stiffening plate at the bending corner part after setting of the stiffening plate. For this reason, future design should increase the angle of the stiffening plate corner and strengthen the configuration of the vertical main tensile steel bar and the surface anticracking steel mesh inside the stiffening plate.

\section{Data Availability}

Stress is one of the main causes of cracks in a polygonal line tower cable-stayed bridge, and the stress reflects the actual force. Only some of the stress data used to support the findings of this study are included within the article, but all stress data used to support the findings of this study are available from the corresponding author upon request. 


\section{Conflicts of Interest}

The authors declare that they have no conflicts of interest.

\section{Acknowledgments}

The authors would like to acknowledge the financial support from the Natural Science Foundation of Liaoning Province (2019-MS-265), the National Key R\&D Program of China (2018YFC0809600 and 2018YFC0809606), and Key Laboratory of the Ministry of Education on Safe Mining of Deep Metal Mines (2019SMDM-KF-A01).

\section{References}

[1] B. Atmaca, T. Dede, and M. Grzywinski, "Optimization of cables size and prestressing force for a single pylon cablestayed bridge with Jaya algorithm," Steel and Composite Structures, vol. 34, no. 6, pp. 853-862, 2020.

[2] M. Virlogeux, "Recent evolution of cable-stayed bridges," Engineering Structures, vol. 21, no. 8, pp. 737-755, 1999.

[3] A. J. Reis and J. J. Oliveira Pedro, "The europe bridge in Portugal: Concept and structural design," Journal of Constructional Steel Research, vol. 60, no. 4, pp. 363-372, 2004.

[4] M. M. Chrimes, "The development of concrete bridges in the British isles prior to 1940," Structures and Buildings, vol. 116, no. 3-4, pp. 404-431, 1996.

[5] W. H. Peng, X. D. Shao, L. F. Li, and Y. Zhang, "Concept, design and construction of cable-stayed bridge without backstays," Journal of Civil Engineering, vol. 40, no. 5, pp. 26-33, 2007.

[6] D. H. Yan, Y. W. He, and H. S. Xu, "The influence of the inclination of the tower of the Changsha Hongshan bridge on the state of its bridge," Journal of Changsha University of Science and Technology (Natural Science Edition), vol. 2, no. 3, pp. 7-11, 2005.

[7] B. Wang, Structural Design and Calculation of the CableStayed Bridge with No Backstays in the Leaning Tower, Southeast University, Nanjing, China, 2006.

[8] G. Y. Huang, Research on Cable-Stayed Bridge without Back Cable, Beijing University of Technology, Beijing, China, 2006.

[9] J. R. Casas, S. Calatrava, and A. C. Aparicio, "The Alamillo cable-stayed bridge: special issues faced in the analysis and construction," Structures \& Buildings, vol. 122, no. 4, pp. 432-450, 1997.

[10] D. W. Chen, F. T. K. Au, L. G. Tham, and P. K. Lee, "Determination of initial forces in prestressed concrete cablestayed bridges for given design deck profiles using the force equilibrium method," ComputersઐStructures, vol. 74, no. 1, pp. 1-9, 2000.

[11] B. S. Smith, "The single palne cable-stayed girder bridge: A method of analysis suitable for computer use," Civil Engineering, vol. 37, no. 5, pp. 183-194, 1967.

[12] Y. Xi and J. S. Kuang, "Ultimate load capacity of cable-stayed bridges," Journal of Bridge Engineering, vol. 4, no. 1, pp. 14-22, 1999.

[13] C. Honigmann and D. P. Billington, "Conceptual design for the sunniberg bridge," Journal of Bridge Engineering, vol. 8, no. 3, pp. 122-130, 2003.

[14] R. Karoumi, "Some modeling aspects in the nonlinear finite element analysis of cable supported bridges," Computers \& Structures, vol. 71, no. 4, pp. 397-412, 1999.
[15] Q. S. Chen, W. L. Huang, and M. G. Yang, "Analysis of shear lag effect in construction stage of wide box girder extradosed cable-stayed bridge with large flanges," Journal of Railway Science and Engineering, vol. 15, no. 12, pp. 3158-3164, 2018.

[16] D. R. Li, B. M. Wang, and Y. C. Lin, Structural Model Experiment, Science Press, Beijing, China, 1996.

[17] J. W. Dali and W. F. Laili, Experiment and Analysis of Residual Stress, Ocean Press, Beijing, China, 1987.

[18] L. H. Han, T. M. Mu, F. C. Wang et al., "Design theory of CFST (concrete-filled steel tubular) mixed structures and its applications in bridge engineering," China Civil Engineering Journal, vol. 53, no. 5, pp. 1-24, 2020.

[19] S. K. Mei, Structural Experiments and Structural Design, China Communications Press, Beijing, China, 1980.

[20] X. Ma, J. Nie, and J. Fan, "Longitudinal stiffness of multispan suspension bridges," Journal of Bridge Engineering, vol. 21, no. 5, 2016.

[21] Y. Geng, G. Ranzi, Y.-T. Wang, and Y.-Y. Wang, "Out-ofplane creep buckling analysis on slender concrete-filled steel tubular arches," Journal of Constructional Steel Research, vol. 140, pp. 174-190, 2018.

[22] C. Y. Liu, Q. Hu, Y. Y. Wang, and S. M. Zhang, "In-plane stability of concrete-filled steel tubular parabolic truss arches," International Journal of Steel Structures, vol. 18, no. 4, pp. 1-12, 2018.

[23] V. Michel, "Bridges with multiple a cable-stayed spans," Structural Engineering International, vol. 11, no. 1, pp. 61-82, 2001.

[24] T. Zordan, B. Briseghella, and T. Liu, "Finite element model updating of a tied-arch bridge using Douglas-Reid method and Rosenbrock optimization algorithm," Journal of Traffic and Transportation Engineering (English Edition), vol. 1, no. 4, pp. 280-292, 2014.

[25] Y. Okamoto and S. Nakamura, "Static and seismic studies on steel/concrete hybrid towers for multi-span cable-stayed bridges," Journal of Constructional Steel Research, vol. 67, no. 2, pp. 203-210, 2011.

[26] X. Y. ZHeng, Y. Xu, and Z. D. Feng, "Performance of longspan multi-tower suspension bridge with the action of static wind," in Proceedings of 2011 International Conference on Electric Technology and Civil Engineering, Lushan, China, April 2011.

[27] J. Li, J. Yan, and T. Peng, "Etal shake table studies of seismic structural systems of a taizhou changjiang Highway bridge model," Journal of Bridge Engineering, vol. 20, no. 3, 2015. 